Boletín de la Sociedad Geológica Mexicana

VOLUMEN 60, NÚM 2, 2008, P. 159 - 171

\title{
Beidellite-nontronite clays in Neogene sediments from Cuitzeo-Charo lacustrine basin Michoacán, México. Geological setting and paleoenvironmental implications
}

\author{
Isabel Israde-Alcántara1,*, Jasinto Robles-Camacho², José Manuel Domínguez ${ }^{3}$
}

${ }^{1}$ Departamento de Geologia y Mineralogía, Instituto de Investigaciones Metalúrgicas. Universidad Michoacana de San Nicolás de Hidalgo, Cd.
Universitaria, 58000 Morelia, Michoacán, México.
${ }^{2}$ Laboratorio de Arqueomería de Occidente, Instituto Nacional de Antropología e Historia, Centro INAH Michoacán, Madero Oriente 799,
Centro, 58000 Morelia, Michoacán, México.
${ }^{3}$ Competencia de Catalizadores y Productos Químicos, Instituto Mexicano del Petróleo, Eje Central Lázaro Cárdenas 152,07730 México, D.
F., México
${ }^{*}$ Email:aisrade@zeus.umich.mx

\begin{abstract}
Lacustrine and fluviolacustrine deposits of the Charo sequence crop out extensively along tens of kilometres, and they overlie the Miocene volcanic sequences of the Mil Cumbres Complex in an E-W oriented basin. Eastwards of Morelia city (central Mexico), layers of non lithified clayey sediments of about $3 \mathrm{~m}$ in thickness are overlaid by massive diatomite deposits developed during the Miocene-Pliocene in the Cuitzeo palaeolake. Major outcrops are located south and east of the village of Charo at the Las Pulgas, Lomas Blancas and Tzitzimeo sites; all having similar mineralogical facies and stratigraphic correlation. Field studies, petrography and X-ray fluorescence spectrometry (XRF) indicated that the parent rock was mainly of andesitic composition with minor dacitic-rhyolitic components. The source of the raw material was located in the upper topographic levels of the present horst-graben system. The diagenetic clays were identified as smectites. The central part of the Las Pulgas column shows a beidellite-nontronite (B-N) association. Likewise, ${ }^{27} \mathrm{Al}-\mathrm{NMR}$ and Mössbauer spectroscopies confirm the B-N character. Interlaid and overlying diatomite strata indicate a lacustrine environment, favourable to the development of secondary clays. The stability of lacustrine conditions gave place to an incipient stratification (smectite-illite), better developed in the middle part of the clayey levels.
\end{abstract}

Key words: Beidellite-nontronite clays, Cuitzeo basin, lacustrine neogene palaeoenvironments, Neogene, stratigraphy, diatomite.

\section{Resumen}

Depósitos lacustres y fluviolacustres de la secuencia de Charo afloran a lo largo de decenas de kilómetros y sobreyacen las secuencias volcanicas del Mioceno del Complejo de Mil Cumbres en una cuenca orientada Este-Oeste. Al oeste de la ciudad de Morelia (centro oeste de Mexico), los estratos arcillosos no litificados con espesores de $3 \mathrm{~m}$ son sobreyacidos por depósitos de diatomita masiva que se desarrollaron durante el Mioceno-Plioceno en el paleolago de Cuitzeo. Los mas grandes afloramientos están localizados al sur y este del poblado de Charo en Las Pulgas, Lomas Blancas y Tzitzimeo, todas conformando facies mineralogicas y correlación estratigrafica similares. Estudios de campo, petrografía y espectrometría de rayos $X(X R F)$ indican que la roca parental fue principalmente de composición andesítica con componentes menores de tipo dacitico y riolítico. La fuente de este material se localiza en los niveles estratigráficos del actual sistema regional de horst y grabens. Las arcillas diagenéticas fueron identificadas como esmectitas. La parte central de la columna de Las Pulgas muestra una asociación de beidellita-nontronita $(B-N)$. Igualmente la ${ }^{27} A l-N M R$ y la espectrometría Mössbauer confirman el carácter B-N. Las diatomitas intercaladas y que sobreyacen estos depósitos arcillosos indican un ambiente lacustre que favoreció la incipiente estratificación (esmectita-illita), que se desarrolla favorablemente en la parte media de los estratos arcillosos.

Palabras clave: Beidellita-nontronita, paleoambientes lacustres, cuenca de Cuitzeo, Neógeno, estratigrafía, diatomita. 


\section{Introduction}

Lacustrine sequences often constitute excellent sedimentary records of geological, palaeoclimatic and palaeoenvironmental changes (Gasse, 1986). In the central part of the Trans Mexican Volcanic Belt (TMVB), large lacustrine basins were developed during the Middle Miocene-Upper Pliocene in a systematic east-west arrangement of horsts and grabens, as a consequence of regional compression and extension tectonism through oblique subduction of the Pacific Plate under the North American Plate (Ortega-Gutiérrez et al., 1992; Garduño-Monroy et al., 1993, Israde-Alcántara and Garduño-Monroy, 1999). Some of these ancient lacustrine basins dried out, but others still preserve a perennial water column, such as the Chapala and Cuitzeo lakes (Figure 1). Previous studies involving Neogene and Quaternary lacustrine basins have been done in the Acambay graben (Rodriguez Pascua et al., 2004), the Chapala rift (Garduño-Monroy et al., 1993; Rosas-Elguera et al., 1997) and the Cuitzeo graben (Israde-Alcántara and Garduño-Monroy, 1999). At the Cuitzeo basin system, lithostratigraphical, biostratigraphical and tectono-stratigraphical process were studied (Israde et al., 1992; Israde-Alcántara, 1995, 1997; Israde-Alcántara and Garduño-Monroy, 1999). The resulting basins were filled with detrital material and water, which provided the natural conditions to produce clay-rich strata (Carbajal et al.,1998). In Mexico, large clay deposits are concentrated along the MVB (Anda, 1956), examples of which are: the hydrothermal kaolinite from La Sierra de San Andres at the Los Azufres geothermal field (Michoacán) (QuintanaPuchol et al., 1999); the former kaolinite mines Near Tepic city (west part of the MVB); the Noche Buena (Guanajuato) zone where the finest kaolinite was formed by hydrothermal alteration of granitic rocks and that is widely used for pottery; the important high quality kaolinite deposits (in the northeastern MVB), which are the product of the alteration of rhyolithic rocks. In contrast with kaolinite deposits, most of the expandable smectites have a sedimentary origin (López-Ramos, 1974; De Pablo-Galán, 1990), examples in Mexico being found in northern Mexico, at Cuencamé, Durango (De PabloGalán, 1990; Vargas-Rodriguez et al., 2008), and in southern Mexico, at the Oaxaca Valley. The Upper Cretaceous is represented by the clays of Parras and Méndez (López-Ramos, 1974; De Pablo-Galán, 1978). Other types of clays such as attapulgite of sedimentary marine origin have been reported in the Yucatan peninsula (De Pablo-Galán, 1976). One of the authors of the present work (Robles-Camacho) identified smectites as a product of hydrothermal alteration of Late Miocene andesites in the Cerro Grande Volcanic area $(10 \mathrm{~km} \mathrm{NW}$ of Libres, Puebla) and, near this area, deposits of nontronite were identified (Von Erffa et al., 1976).

Since the objective of the present research was to understand the origin of the clayey strata at southern Cuitzeo and the diagenetic process involved, representative rocks in this region were sampled, on the basis of their geological history (Figure 2a). The present work reports clays from northern Michoacán state (Mexico) and their biostratigraphic relation in the lacustrine sediments from the Morelia-Charo sub-basin, with special remarks in the clayey and diatomite members from northern Michoacán state.

\section{Materials and analytical methods}

Clay materials were collected from three major localities between roads 120 and 15, NE of Morelia city. A total of 30 sites were sampled but, in the present paper, data of only the three most representative localities are reported: 1) Tzitzimeo (TZ-C), located at the north-eastern limit of the study area; 2) Lomas Blancas (LB-B); and 3) Las Pulgas (LP-A), the latter two sections located in the central basin (Figure 2b), and which allowed the correlation between different outcrops. At the basal part of the clayey column an oxidized level was found that was used as a marker horizon.

Petrographic analyses of the clays and their associated minerals were made from samples mounted with epoxy resin and observed with a II POL-BK Leitz polarized light microscope. X-ray diffraction analysis was performed on a SIEMENS-D5000 diffractometer equipped with a $\mathrm{Cu}_{\lambda=1.54 \AA}$ cathode. The samples were ground using an agate mortar and then placed on a Mylar holder. The clay samples were oriented to distinguish the main peaks that arise from the basal 001 crystallographic plane. A suspension was made from $50 \mathrm{mg}$ of the grinded samples in $50 \mathrm{ml}$ of distilled water and treated in an ultrasonic bath (10 min) until complete disaggregating and sedimentation. After $24 \mathrm{~h}$ the samples were collected using a micropipette and deposited on glass slides for the XRD studies. Cumulated clayey samples were deposited on a bronze cylinder and covered with graphite for morphological and chemical microanalysis performed by means of a $\mathrm{Si} / \mathrm{Li}$ detector (Tracor Northern-5500) fitted to a scanning-transmission microscope (Jeol $100 \mathrm{CX}$ ), which was operated at $40 \mathrm{Kv}, 100$ sec, from 0 to $40 \mathrm{KeV}$. Analyses of whole rock and of the pure clay fractions from the ground level were made by X-ray fluorescence spectrometry (XRF) using a SIEMENS SRS 3000, in order to compare the original composition of those rocks with other possible sources and their alteration products.

Due to the environmental implications of clayey strata and the external influence from geological adjacent units in their structural changes, upper and lower strata constituted by diatomite were systematically sampled each $15 \mathrm{~cm}$ from bottom to top. In order to remove the carbonates, these samples were dried and ground and $0.5 \mathrm{~g}$ of the powder boiled in hydrochloric acid below $100^{\circ} \mathrm{C}$. After this, water was added to obtain a neutral $\mathrm{pH}$. The procedure was repeated with hydrogen peroxide to remove organic matter. The prepared samples were normally diluted to $500 \mathrm{ml}$ and a $2 \mu \mathrm{l}$ aliquot was mounted in Nafrax (a high refraction index solution) for microscopic observations using an Olympus Bymax 50 at 1000x.

\subsection{Geological setting}

In the north of the state of Michoacan (central part of the TMVB), significant deposits of clayey sediments are observed in the Cuitzeo basin (Figure 2a), after Chapala, the second 


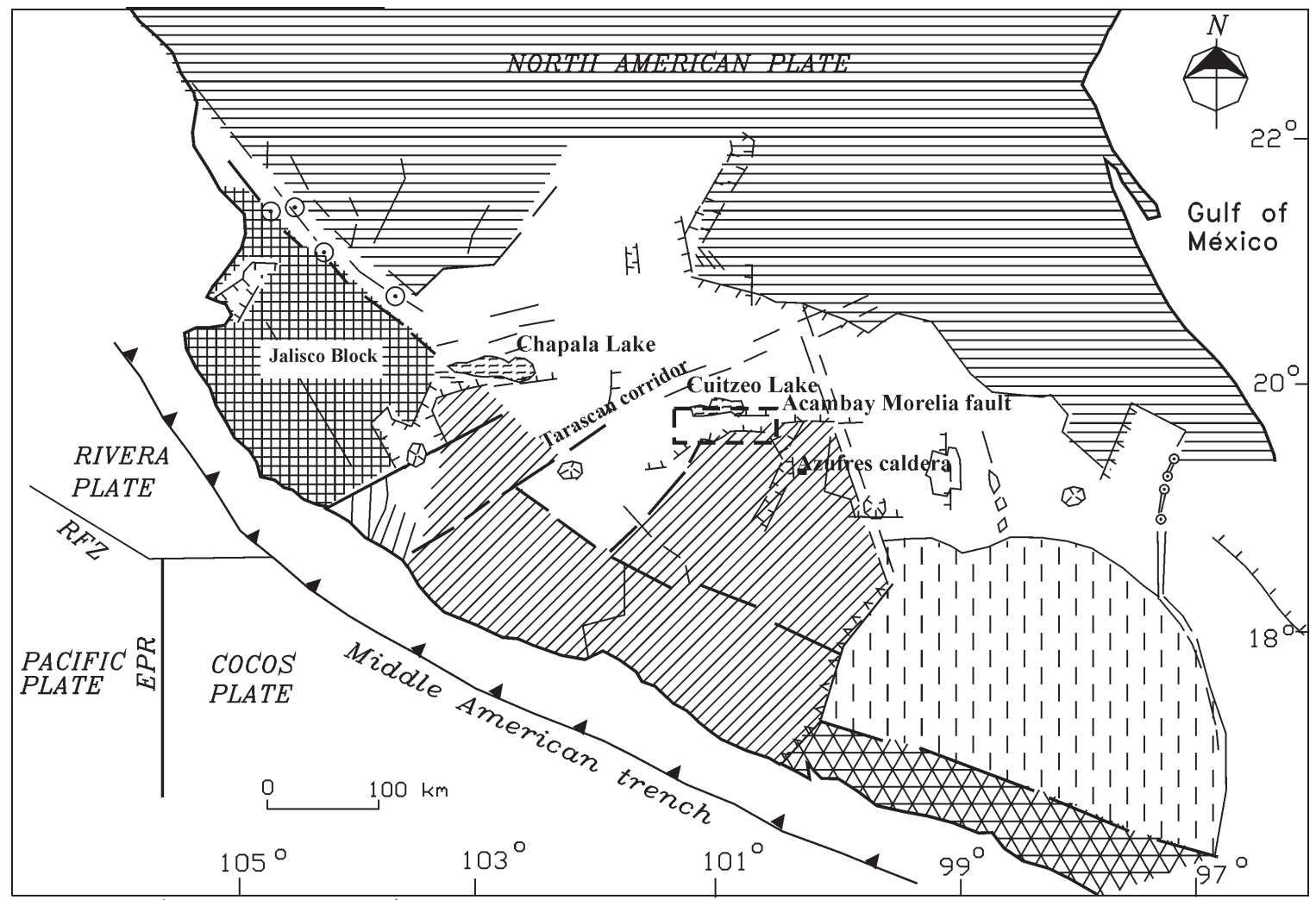

1)Normal faults 2) Mainfaults; 3)Volcanic center; 4)Principal thrust

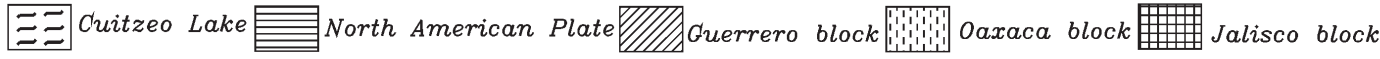

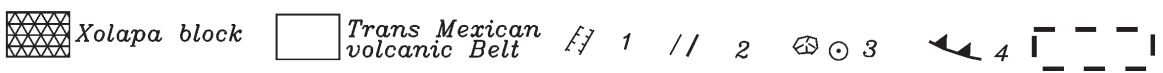

Figure 1.- Sketch showing fundamental architecture of the Trans Mexican Volcanic Belt Central Mexico and distribution of main lacustrine basins indicating the study area.

largest basin at regional scale (Figure 1). Late Miocene to Quaternary lacustrine and alluviolacustrine sequences was deposited in the Charo-Morelia sub-basin, south of the modern Cuitzeo lacustrine depocenter. This depression is bordered to the south by contemporary volcanites of the Mil Cumbres succesion (Pasquaré et al., 1991), to the east by the Los Azufres Caldera (Garduño, 1988), to the west, by outcrops of PlioQuaternary calc-alkaline volcanics. A south tilting of the Miocene block produced emergence and exposure of lacustrine and fluviolacustrine sequences as well as the successive filling of the Cuitzeo basin, which is part the Charo-Morelia depression. Today, the area is drained by the Rio Grande de Morelia, which flows along a preferential E-W direction.

Upper Miocene andesitic rocks dated at $8 \pm 0.2 \mathrm{My} \mathrm{K} / \mathrm{Ar}$ underlies the basin (CFE, 1986). These rocks are hornblende andesites, essentially composed by sodic plagioclase, andesine, oligoclase, hornblende, lamprobolite, augite, chlorite, stilbite and magnetite (CFE, 1986). The andesitic lavas are overlaid by fluviolacustrine, lacustrine, and epiclastic deposits of the Charo Formation (Demant et al., 1975; Israde-Alcántara and Garduño-Monroy, 1999) along a NE-SE oriented belt. Interlaid on the top of the fluviolacustrine sequences there are levels of Early Pliocene cinder, dated at 3.6 My K/Ar (Car-
ranza-Castañeda, 1976). Plio-Quaternary domes, stratovolcanoes, epiclastic and pyroclastic deposits are scattered throughout the whole area.

The andesitic basement ( 8 to $13 \mathrm{My}$ ) and the alluviolacustrine sequences of the top Charo sequence (i.e. 3.6 My) suggest that, the evolution of the ancient lacustrine zones in the Charo-Morelia sub-basin spanned a time period of about 5.5 My. The undisturbed lacustrine sedimentation took place from the inner to the marginal basin zones.

Considering the characteristic distinctive lithofacies of the Charo sequence, and the unconformity surfaces bounding some of these, three main stages can be distinguished in the main depositional processes:

1) An initial shallow lake and the development of swampy zones, in which alluvial deposits, shallow lacustrine diatomaceous horizons and thin clay strata were deposited. During this first evolutionary stage (Charo sub-unit Ba) lacustrine deposition took place only at the central zones of the Charo-Morelia sub-basin, delimited by the NE-SW oriented strike-slip fault alignments.

Lacustrine sedimentation was characterized by alternating silts and clays deposited in marshy to deltaic environments. Diatomite deposits are thin and often include littoral-epiphyt- 
ic diatom assemblages. The dominant diatom flora recorded in the LP section (Mastogloia elliptica var dansei (Twaites), Cleve Muller, Rophalodia gibba (Ehrenberg), Cymbella cymbiformis (Agard), Epithemia sorex (Kutzing) and Punctastriata pinnata (Ehrenberg)) characterizes shallow waters in which there were changes in the water level and nutrients. In the channel bodies, fine sands with flasser and low angle cross bedding are common. On the top of this basal member, a 5 $\mathrm{cm}$ thick oxidized strata represents an isochronous marker bed that may be traced laterally in most of the sections throughout the basin; this oxidized level suggests that the lacustrine bottom underwent desiccation and/or subaerial exposure caused by a fall in the water level. This is an evidence of climatic or tectonic changes in the watershed.

2) The second stage (Early Pliocene) is characterized by NE-SW extensional basins (Israde-Alcántara and GarduñoMonroy 1999) where the Charo-Morelia lacustrine depocenter became largest. The spreading gave opportunity to a main transgression that developed a deeper but although still shallow subtropical lake. The basin was filled by clayey rich sediments in the initial phase, and afterwards, by diatomite facies. In this event the lake attained its maximum area and the most long-lived lacustrine period was recorded. The planktonic and planktonic-facultative lacustrine diatom assemblages record the development of a major lake transgression, including Aulacoseira granulata (Ehrenberg) and A. praeislandica (Jousé); which indicates a remarkable water level rise which could have been caused by wetter climate, or by a tectonic watershed with drainage rearrangement. The optimum environmental conditions for clay development are deep enough lacustrine conditions and a marked stabile water body with no big amounts of detrital inputs to permit the successive sedimentation of the clays.

3) In a third stage, coarse-grained alluvial-fluvial deposits seem to be tightly controlled by the watershed and drainage changes caused by the widespread tilting. The restricted small lakes and pond related environments led to the development of thin clays and diatomite deposits that were fed by ephemeral fluvial currents (Figure 2b).

Pyroclastic fall deposits filled these minor water bodies during a major acidic volcanic episode. Quaternary alluvial, marshy and volcanic assemblages discordantly overly the above mentioned units. The youngest deposits in the basin are related to the recent alluvial and volcanic episodes such as the Quinceo volcanic shield, whose earlier emissions are from the Late Pleistocene 500 ky.b.P (Suter et al., 2001).

The major clay outcrops are observed in the southern sector of the modern Cuitzeo Lake, $5 \mathrm{~km}$ east of the city of Morelia. Large isolated outcrops are also seen in the TZ site, northeast of Charo and to the north, towards the town of Cuitzillo Grande (Figure 2). In the LP sector, located south of the village of Charo, there is a detailed succession of clay and silt strata. The clay beds occupy interlaid strata of 1.5 to $3 \mathrm{~m}$ in thickness, which are composed of fine, black to clear-brown-colour clayey material and may also show up as a very fine stratification with a soapy lustre texture. Commonly, at the base of the clayey strata there is a strongly oxidized ochre-colour horizon of about $5 \mathrm{~cm}$ thickness, which indicates a lake regression by tectonic (uplift) or climatic (dryness) effects. Another possible explanation may be based on the occurrence of rapid oxidation of pyrite deposits on a swampy medium (lake), after a volcanic exhalation.

The ecological evolution and probable extension of the ancient lacustrine zones in the Charo-Morelia sub-basin was defined on the basis of the analysis of stratigraphy, diatom assemblages and sedimentological data obtained from twelve closely related reference sections (Israde-Alcántara and Garduño-Monroy, 1999). Three selected sections were studied for clays and two for diatom analysis, these last due to the fact that diatoms are well represented and are very sensitive organisms that accurately record the physicochemical environment of ancient lakes at the time they are finally included in the sediment. On the base of this sensitivity and taking into account the modern distribution of diatom species or diatom assemblages, it is therefore possible to determine the diverse sub-environments and overall paleoenvironmental conditions of ancient lacustrine systems. Diatomites, together with sedimentary facies, allow establishing the paleohydrological evolution of ancient lakes.

In these studied sections the diatomite and clayey strata are found outcropping at elevations close to $1900 \mathrm{~m}$ a.s.l. In the gorges of the Charo basin, the upper basin infill crops out in the cliffs along the Atapaneo-Lomas Blancas sector, reaching an altitude of $1940 \mathrm{~m}$ a.s.l. (Figure 2a).

\section{Results and discussion}

\subsection{Mineralogical and geochemical constraints}

Petrographic analysis of rocks from the southern part of the basin shows the dominance of andesites (Table 1 and 2), which generally occur SE, S and SW of the LP and LB sites (Figure 2 a). The microscopic observations of rocks from east Morelia and south of Charo, allowed confirming that andesitic rocks constitute the main outcrops representing the base of the local column. The andesite deposits are overlapped by a fluviolacustrine succession predominantly with clayey and diatomaceous members.

The physical and mineralogical properties of the basal andesitic rocks of the LP (A), LB (B) and TZ (C) sites in the Cuitzeo palaeolake show evidence of alteration. Likewise, the clay minerals identified as secondary products of weathering in the same rocks, are illite, chlorite and smectites.

As the degree of alteration depends on tectonic, hydrothermal and weathering effects, there are quantitative features that show a relationship between outcrops and tectonic settings; for this reason, the samples M-6, M-7 and M-8, have alteration ranges of between a $13 \%$ and a $24 \%$ of the whole rock, being the most advanced, because they are located in a faulted top block and a strike slip block of the Morelia-Acambay Fault System (Suter et al., 1992). Sample M-9 does not shows any evidence of advanced alteration, either because it could be a part of more recent volcanism as compared with the "base of column" or because it is out of the main tectonic influence; as are the samples M-1, M-2 and M-3. The most abundant rocks 


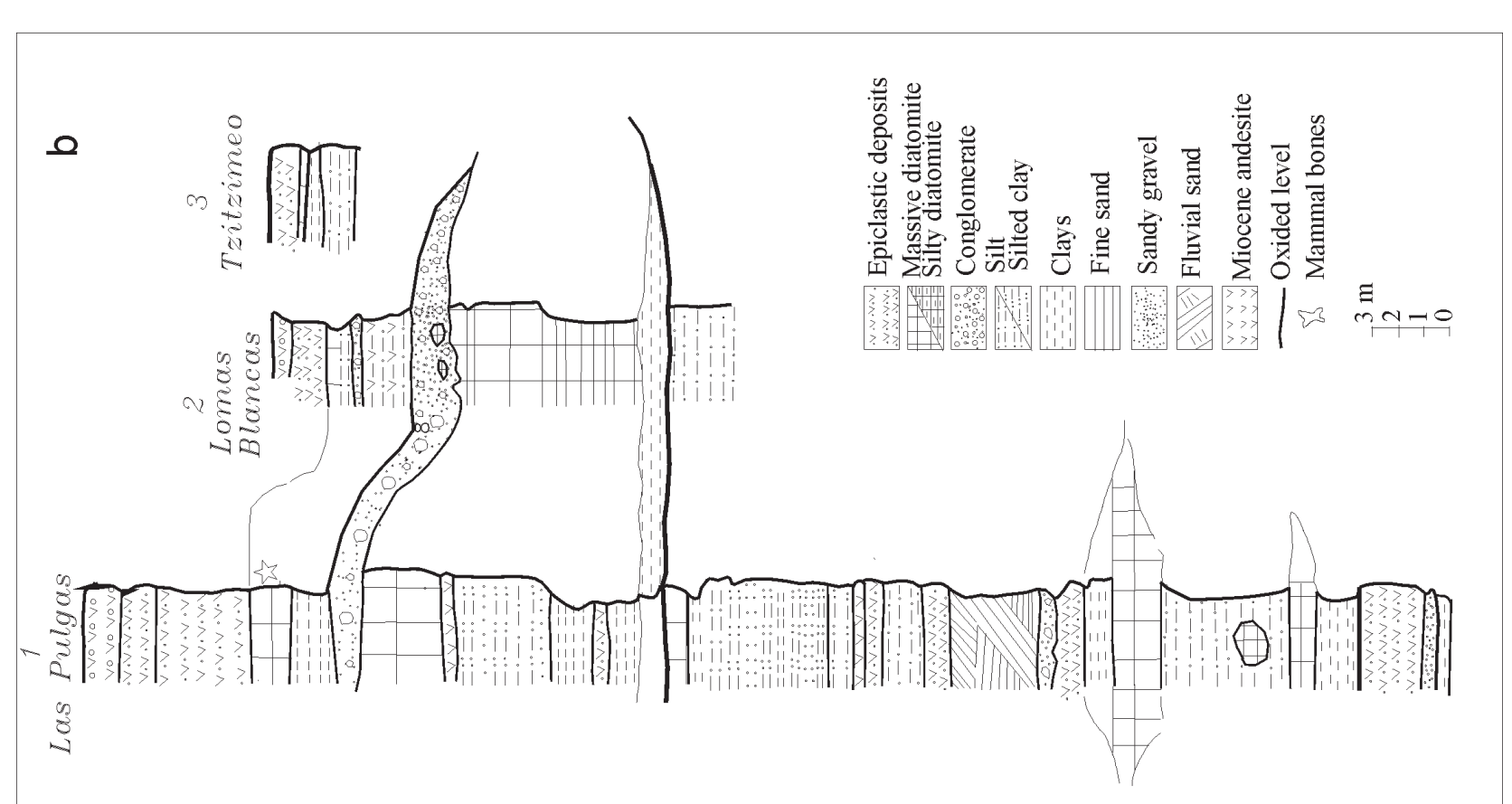

作

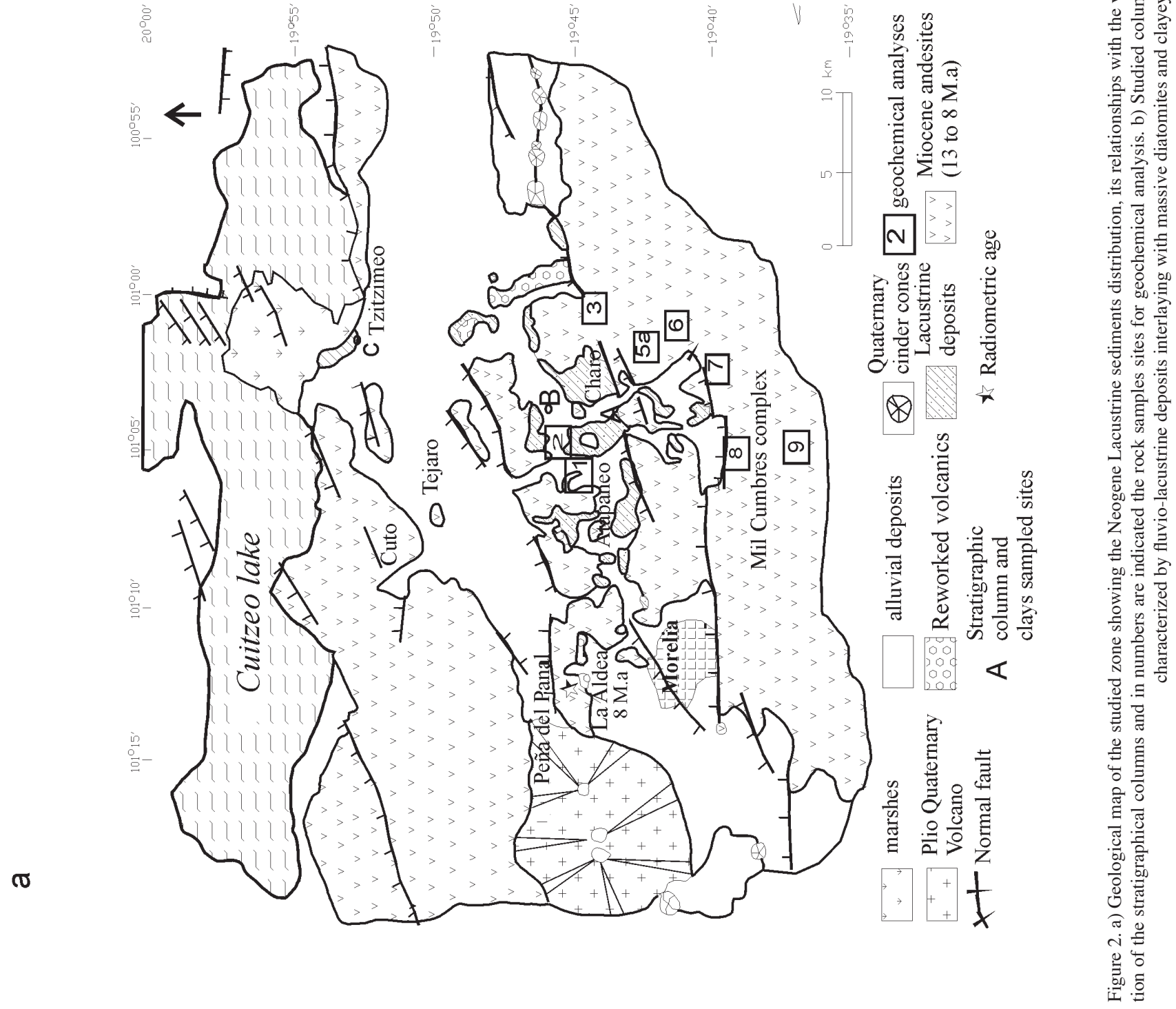


Table 1. Petrographic characteristics of volcanic rocks from east Morelia city.

\begin{tabular}{|c|c|c|c|c|c|c|c|}
\hline $\begin{array}{l}\text { SAMPLE/ } \\
\text { LOCALITY }\end{array}$ & ROCK & ABBREVIATION & $\begin{array}{l}\text { PRIMARY } \\
\text { MINERALS }\end{array}$ & $\begin{array}{l}\text { ACCESSORY } \\
\text { MINERALS }\end{array}$ & MATRIX & $\begin{array}{l}\text { SECONDARY } \\
\text { MINERALS }\end{array}$ & $\begin{array}{l}\text { ALTERATION } \\
\text { RANGE }\end{array}$ \\
\hline $\begin{array}{l}\text { M-1 } \\
\text { La Goleta }\end{array}$ & $\begin{array}{l}\text { enstatite } \\
\text { andesite }\end{array}$ & EAND & $\begin{array}{c}\text { olg-and } \\
(55-65 \%)\end{array}$ & $\begin{array}{c}\text { ens }(8-10 \%) \\
\text { aug }(<2 \%) \\
\text { mt }(4 \%)\end{array}$ & glss $(8 \%)$ & $\begin{array}{c}\operatorname{clym}(5 \%) \\
\text { he }(2 \%) \\
\text { cl }(1 \%)\end{array}$ & $8 \%$ \\
\hline $\begin{array}{l}\text { M-2 } \\
\text { El Zapote }\end{array}$ & $\begin{array}{l}\text { augite } \\
\text { andesite }\end{array}$ & AAND & $\begin{array}{c}\text { olg-and } \\
(45-55 \%)\end{array}$ & $\begin{array}{c}\text { aug } \\
(20-25 \%) \\
\text { mt }(4-6 \%)\end{array}$ & $\begin{array}{c}\text { glss } \\
(10-12 \%)\end{array}$ & $\begin{array}{c}\text { he }(4-6 \%) \\
\text { clym }(<1 \%) \\
\operatorname{cl}(<1 \%)\end{array}$ & $7 \%$ \\
\hline $\begin{array}{l}\text { M-3 } \\
\text { El Cuervo }\end{array}$ & $\begin{array}{l}\text { augite- } \\
\text { enstatite } \\
\text { andesite }\end{array}$ & AEAND & $\begin{array}{c}\text { olg-and } \\
(55-65 \%)\end{array}$ & $\begin{array}{c}\text { Aug } \\
(12-15 \%) \\
\text { ens }(<2 \%) \\
\text { mt }(2-5 \%)\end{array}$ & $\begin{array}{c}\text { glss } \\
(10-12 \%)\end{array}$ & $\begin{array}{c}\mathrm{Qz}(<2 \%) \\
\text { clym }(<2 \%) \\
\text { he }(<1.5 \%)\end{array}$ & $5 \%$ \\
\hline $\begin{array}{l}\text { M-5A } \\
\text { Uña } \\
\text { de Gato }\end{array}$ & $\begin{array}{l}\text { vitreous- } \\
\text { cristaline } \\
\text { vitreous- } \\
\text { tuff. } \\
\text { Devitrifyed }\end{array}$ & VCT & $\begin{array}{l}\operatorname{cf}(3-5 \%) \\
\operatorname{lit}(<3 \%)\end{array}$ & $\mathrm{mt}(5 \%)$ & $\begin{array}{l}\text { glss } \\
(<5 \%)\end{array}$ & $\begin{array}{c}\text { clym + cri } \\
(80 \%) \\
\text { he }(<3 \%)\end{array}$ & $82.5 \%$ \\
\hline $\begin{array}{l}\text { M-6 } \\
\text { Mil } \\
\text { Cumbres }\end{array}$ & $\begin{array}{l}\text { hypestene } \\
\text { andesite }\end{array}$ & HAND & $\begin{array}{c}\text { olg-and-lab } \\
(40-50 \%)\end{array}$ & $\begin{array}{c}\text { Hy } \\
(10-15 \%) \\
\mathrm{mt}(8-10 \%)\end{array}$ & $\begin{array}{c}\text { glss } \\
(6-10 \%)\end{array}$ & $\begin{array}{c}\text { clym + ill } \\
(8-10 \%) \\
\text { he }(2-4 \%)\end{array}$ & $13 \%$ \\
\hline $\begin{array}{l}\text { M-7 } \\
\text { Mesa de } \\
\text { Ayala }\end{array}$ & $\begin{array}{c}\text { augite } \\
\text { enstatite } \\
\text { andesite }\end{array}$ & AEAND & $\begin{array}{l}\text { olg-and } \\
(25-30 \%)\end{array}$ & $\begin{array}{c}\text { aug }(6-8 \%) \\
\text { ens } 2-4 \%) \\
\text { mt }(4 \%)\end{array}$ & $\begin{array}{l}\text { glss } \\
(30 \%)\end{array}$ & $\begin{array}{c}\mathrm{He} \\
(15-20 \%) \\
\operatorname{cl}(2-4 \%)\end{array}$ & $24 \%$ \\
\hline $\begin{array}{l}\text { M-8 } \\
\text { Unión }\end{array}$ & $\begin{array}{c}\text { augite } \\
\text { andesite }\end{array}$ & AAND & $\begin{array}{c}\text { olg-and } \\
(40-50 \%)\end{array}$ & $\begin{array}{c}\text { aug } \\
(12-15 \%) \\
\mathrm{mt}(8-10 \%)\end{array}$ & $\begin{array}{c}\text { glss } \\
(6-10 \%)\end{array}$ & $\begin{array}{c}\text { Qz }(6-10 \%) \\
\text { clym + mic } \\
(4-6 \%) \\
\text { he }(<2 \%)\end{array}$ & $17 \%$ \\
\hline $\begin{array}{l}\text { M-9 } \\
\text { El Viejito }\end{array}$ & $\begin{array}{l}\text { augite- } \\
\text { hyperstene } \\
\text { andesite }\end{array}$ & AHAND & $\begin{array}{c}\text { olg-and } \\
(30-35 \%)\end{array}$ & $\begin{array}{c}\text { aug } \\
(12-15 \%) \\
\text { hy }(2-5 \%)\end{array}$ & $\begin{array}{c}\text { glss } \\
(35-40 \%)\end{array}$ & $\begin{array}{c}\text { clym }(<3 \%) \\
\operatorname{cl}(<2 \%) \\
\text { he }(<1 \%)\end{array}$ & $5 \%$ \\
\hline
\end{tabular}

olg = oligoclase $;$ and = andesine $;$ aug = augite $;$ ens = enstatite $;$ hy = hyperstene $; \mathrm{mt}=$ magnetite $;$ glss = glass clym = clay min-

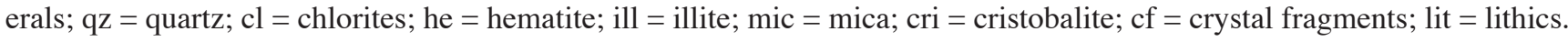

in this zone are classified as andesites and the clay minerals (smectites) are a part of their secondary mineralogy. All those components are the initial leaching source phase of the clayey strata.

Table 2 summarizes the major and minor elements measured in eight rocks belonging to the Morelia site. From these results it is observed that all the lavas belong to the andesites domain (Table 2 and Figure 3a) and display typical calc-alkaline character (Figure 3b). Only the samples Nr. 3 and 9 fell within the dacite field. Sample Nr. 6, collected at the Uña de Gato site showed petrographic characteristics of basic hyperstene andesite, but chemical analysis indicate that it was better placed in the andesites domain. As observed, the most abundant rocks in this zone were identified as andesites, their secondary mineralogy being a product of tectonic, hydrothermal and weathering effects. The weathering and erosion of pre-existing rocks (mainly andesites) contributed to the basin filling, i.e. detritus that were in part smectites and also transformed to clayey strata having a smectitic character after a diagenetic process.

\subsection{Structural details of clays}

One particular feature of the basal clastic sequence at Las Pulgas site (into level 5), has been studied by petrography and $\mathrm{X}$-ray diffraction (XRD) methods. The mineralogical analy- 
a)

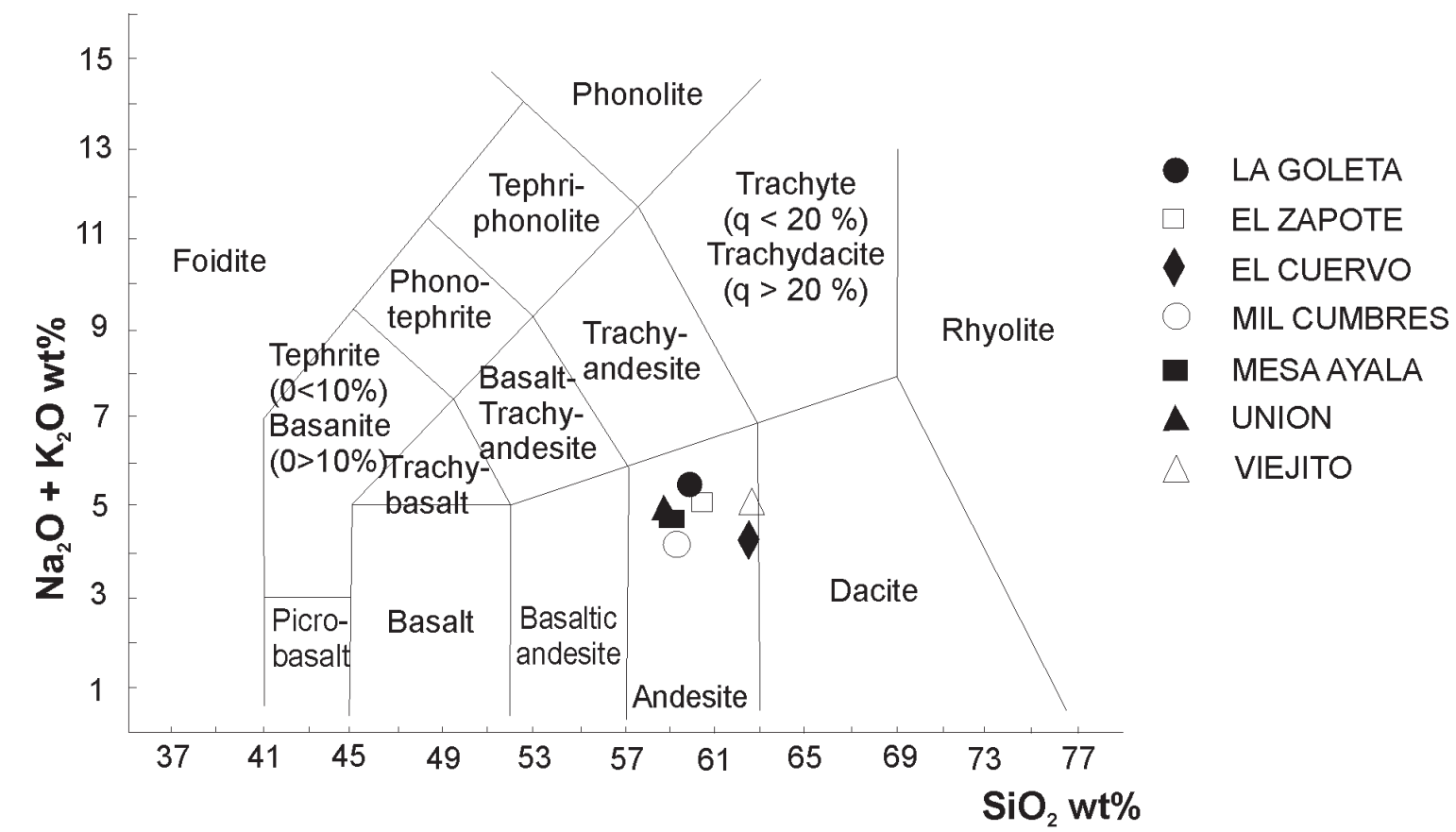

b)

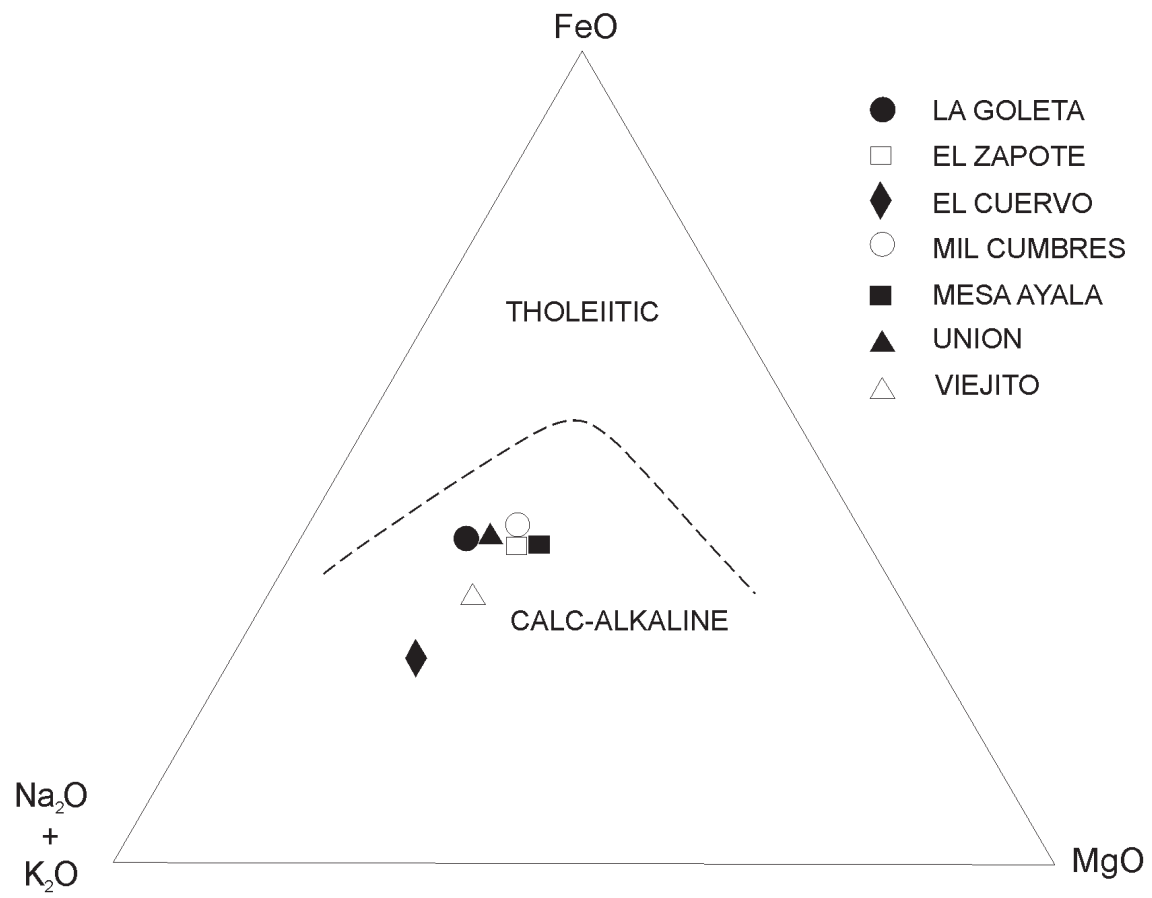

Figure 3. a) Chemical characterization of volcanic rocks from east Morelia city, using total alkali vs. silica (TAS) diagram (from Le Maître, 1989). These rocks also represent the base of the local column. b) Determination of calc-alkaline character of volcanic rocks using total alkalis, ferric and magnesium (AFM) triangular diagram (From Irvine and Baragar, 1971).

sis shows uniform clayey arrangement that contains traces of sub-rounded to angular quartz, feldspar, cristobalite and mica crystals.

The bulk chemical composition of the Charo clays (i.e. LP5-1 basal level) is reported in Table 3. Other clays from Wyoming, Durango (North Mexico) and Puebla (Southeast
Mexico) that were identified previously as Montmorillonites, are also displayed in the same table for comparison. The iron and aluminum content of the LP5-1 Charo clays (Table 3) are higher with respect to the reference clays, but the content of some exchangeable cations like $\mathrm{Na}^{+}$and $\mathrm{Ca}^{2-}$ were found similar. In turn, the EDS data showed that apart Fe, the Charo 
Table 2. Major and minor elements of rocks from east Morelia city.

\begin{tabular}{lllllllll}
\hline Sample & M-1 & M-2 & M-3 & M-5A & M-6 & M-7 & M-8 & M-9 \\
\hline $\mathrm{SiO} 2$ & 60.00 & 60.20 & 62.60 & 57.40 & 59.20 & 59.00 & 59.80 & 62.90 \\
$\mathrm{TiO} 2$ & 0.27 & 0.17 & 0.03 & 0.01 & 0.25 & 0.18 & 0.23 & 0.23 \\
$\mathrm{~A} 2 \mathrm{O} 3$ & 16.80 & 16.50 & 14.50 & 22.10 & 17.80 & 17.00 & 17.50 & 16.70 \\
$\mathrm{Fe} 2 \mathrm{O} 3$ & 6.05 & 6.43 & 2.46 & 3.87 & 6.03 & 6.26 & 5.78 & 4.18 \\
$\mathrm{Cr} 2 \mathrm{O} 3$ & 0.01 & 0.02 & $<0.01$ & $<0.01$ & 0.02 & 0.01 & 0.02 & 0.02 \\
$\mathrm{MnO}$ & 0.06 & 0.12 & 0.05 & $<0.01$ & 0.07 & 0.11 & 0.05 & 0.05 \\
$\mathrm{MgO}$ & 2.39 & 3.18 & 1.62 & 0.34 & 2.87 & 3.45 & 2.40 & 2.49 \\
$\mathrm{CaO}$ & 5.92 & 6.17 & 1.43 & $<0.01$ & 6.66 & 6.79 & 6.22 & 5.68 \\
$\mathrm{Na} 2 \mathrm{O}$ & 3.66 & 3.32 & 1.32 & 0.07 & 3.50 & 3.21 & 3.54 & 3.14 \\
$\mathrm{~K} 2 \mathrm{O}$ & 1.82 & 1.85 & 3.25 & 0.19 & 1.03 & 1.68 & 1.38 & 1.88 \\
$\mathrm{P} 2 \mathrm{O} 5$ & 0.27 & 0.17 & 0.03 & 0.01 & 0.25 & 0.18 & 0.23 & 0.23 \\
$\mathrm{Total}$ & 100.1 & 100.1 & 100.2 & 100.4 & 100.1 & 100.0 & 100.2 & 100.1 \\
$\mathrm{LOI}$ & 2.05 & 1.65 & 12.90 & 15.20 & 1.80 & 1.75 & 2.30 & 2.30 \\
\hline
\end{tabular}

clays had higher percentages of $\mathrm{Ca}, \mathrm{K}$ and $\mathrm{Mg}$ at the sub-surface level (Table 3).

From this chemical composition the structural formula of the Charo clays was calculated as follows:

$\left[\mathrm{Ca}_{0.161} \mathrm{~K}_{0.0995} \mathrm{Na}_{0.0162}\right]\left[\mathrm{Al}_{1.556} \mathrm{Mg}_{0.178} \mathrm{Fe}_{0.279}\right]\left[\mathrm{Si}_{3.672} \mathrm{Al}_{0.327} \mathrm{O}_{10}\right]$ $(\mathrm{OH}) 2$

Xc $=+0.4385, \quad$ Xocth $=-0.1357 \quad$ Xteth $=-0.3277$

The net residual charge is equal to -0.4634 , which falls into the interval for beidellites. This negative charge excess that occurs mainly in the tetrahedral layers is due to the substitution of $\mathrm{Si}$ (IV) by $\mathrm{Al}$ (III), which makes it that Charo clays be a member of the beidellite series.

A typical x-ray diffraction pattern for the Charo clays is displayed in Figure $4 \mathrm{a}$ ), where the basal peak around $5^{\circ}(2 \Theta)$ indicate a layered structure expansion of about $6 \AA$. Cristalline impurities are apparent around $22^{\circ}(2 \Theta)$, indicating the presence of cristobalite traces. As observed in Figure $4 b$, a dspacing shift occurs upon additional water intercalation and/or glycolation (EG). XRD peak at $15.85 \AA$ correspond well to the presence of two intercalated water layers, while the shift to $d=21.08 \AA$ indicates that additional awelling occurred upon humidification. The smaller peak at $d=25.5 \AA$ might be due either to a small fraction of interstratified layers (Brindley and Brown, 1984), i.e. illite-smectite (beidellite) or to the effect of osmotic pressure. In any case, the layer swelling occurrence upon humidification is not a very regular one, but a partial delamination seems apparent (Figure 4b). Comparatively Figure $4 c$, shows the X-ray diffractograms corresponding to a Namontmorillonite (Puebla) clay that was treated under water $8 \mathrm{a}$ vapor pressure of $\mathrm{P} / \mathrm{Po}-0.8)$; one observes in this case that the basal peak is more symmetrical and the peak shift is more regular than the Charo clays (Figure 4b); probably, the layered structure of the Charo clays is held together by Van der Waals forces a little weaker with respect to the reference clays, i.e.
Table 3. Chemical composition of Charo clays (wt\%) and other clayey samples from Mexico, determine by atomic absorption (AA) and energy dispersive spectrometry (EDS).

\begin{tabular}{cllllllll}
\hline Method & CLAYS & $\mathrm{SiO}_{2}$ & $\mathbf{A l}_{2} \mathbf{O}_{\mathbf{3}}$ & $\mathbf{M g O}$ & $\mathbf{C a O}$ & $\mathbf{F e}_{2} \mathbf{O}_{\mathbf{3}}$ & $\mathbf{K}_{\mathbf{2}} \mathbf{O}$ & $\mathbf{N a}_{\mathbf{2}} \mathbf{O}_{3}$ \\
\hline \multirow{2}{*}{ AA } & Charo & 61.24 & 26.63 & 1.99 & 2.51 & 6.19 & 1.30 & 0.14 \\
& Durango & 70.09 & 17.67 & 4.17 & 0.63 & 2.72 & 0.62 & 4.06 \\
& Puebla 1 & 71.67 & 17.91 & 3.65 & 2.27 & 2.77 & 0.53 & 1.19 \\
\multirow{4}{*}{ EDS } & Puebla 2 & 80.01 & 12.09 & 3.61 & 3.12 & 0.91 & 0.09 & 0.13 \\
& Charo & 56.61 & 16.43 & 2.95 & 4.23 & 17.71 & 2.07 & ---
\end{tabular}

Figure $4 c$. These hydration, which in turn means that stronger repulsion may be associated with the higher layer charges in the Charo clays, as expected for a beidellitic clay.

The ${ }^{27} \mathrm{Al}-\mathrm{NMR}-\mathrm{MAS}$ spectra of the Charo clays are shown in Figure 5. This shows a sharp peak with $\delta$ (isometric shift) $=1.868$ ppm, i.e. octahedral aluminum $\left(\mathrm{Al}^{\mathrm{VI}}\right)$ in a slightly distorted environment. The second peak appearing at $\delta=53.63$ ppm falls into the interval corresponding to tetrahedrally coordinated aluminum $\left(\mathrm{Al}^{\mathrm{VI}}\right)$. The proportion of one species with respect to the other was determined by means of the ${ }^{27} \mathrm{Al}-\mathrm{NMR}$ peak areas, as displayed in Figure 3 , where the ratio $\mathrm{Al}^{\mathrm{IV}} / \mathrm{Al}^{\mathrm{VI}}=$ ${ }^{1 / 4} .7506=0.21$. That is $17.5 \%$ with respect to the total $\mathrm{Al}$, i.e. $\mathrm{Al}^{\mathrm{IV}} /\left(\mathrm{Al}^{\mathrm{IV}}+\mathrm{Al}^{\mathrm{VI}}\right)=0.175$. Thus, the ${ }^{27} \mathrm{Al}-\mathrm{NMR}$ spectra confirm the substitution of $\mathrm{Si}$ (IV) by $\mathrm{Al}$ (III) in the tetrahedral sheet, or $1 \mathrm{Al}^{\mathrm{IV}}$ out of $4.7 \mathrm{Al}^{\mathrm{VI}}$ atoms, thus proving the beidellitic character of the Charo clays. The $17.5 \%$ of $\mathrm{Al}^{\mathrm{IV}}$ with respect to the total aluminum ( AlIV+AlVI) represents a high substitution degree in comparison with other clays, for example the Durango clays have a AlIV/AlVI ratio equal to $1 / 40=0.025$, or $2.4 \%$ of total aluminum ( AlIV+AlVI), which is about 10 times less than the Charo clays.

One detail more about this special clays is supplied by Mössbauer spectroscopy, where Durango clays, like standard, contains $2.72 \%$ of iron oxide. This side lines are indicative of the presence of $\alpha-\mathrm{Fe}_{2} \mathrm{O}_{3}$ phases spreaded out on the clay flakes (Brindley and Brown, 1984). The spectrum corresponding to the Charo clays does not have the side lines as shown by Figure 6 , but a central quadrupole doublet is apparent, which is consistent with $\mathrm{Fe}_{2} \mathrm{O}_{3}$ phases in a distinct chemical environment, for example the structural Fe (III). In this case the isomer shift is equal to $0.32 \mathrm{~mm} / \mathrm{s}$, which is assigned to $\mathrm{Fe}$ (III) in the octahedral configuration proper of 2:1 structures (Nolet and Burns, 1979). In comparison with Mössbauer spectrum of nontronite, which is known to contain Fe (III) in octahedral coordination, this has a doublet similar to the one shown in Figure 6, but it is about 10 times more intense (i.e. the number of $\mathrm{Fe}^{\mathrm{VI}}$ cations is larger). Here again the side lines are not apparent and the isomer shift $(\delta)$ is equal to $0.32 \mathrm{~mm} / \mathrm{s}$, similarly to $\delta$ in the case of the Charo clays; this confirms that chemical environment of $\mathrm{Fe}$ (III) in the Charo clays is similar to Fe (III) in nontronites, that is the octahedral coordinated species. The origin of this particular configuration may be related to the cationic of $\mathrm{Al}$ (III) by $\mathrm{Fe}$ (III) that occurs during the clay diagenesis. 
a)

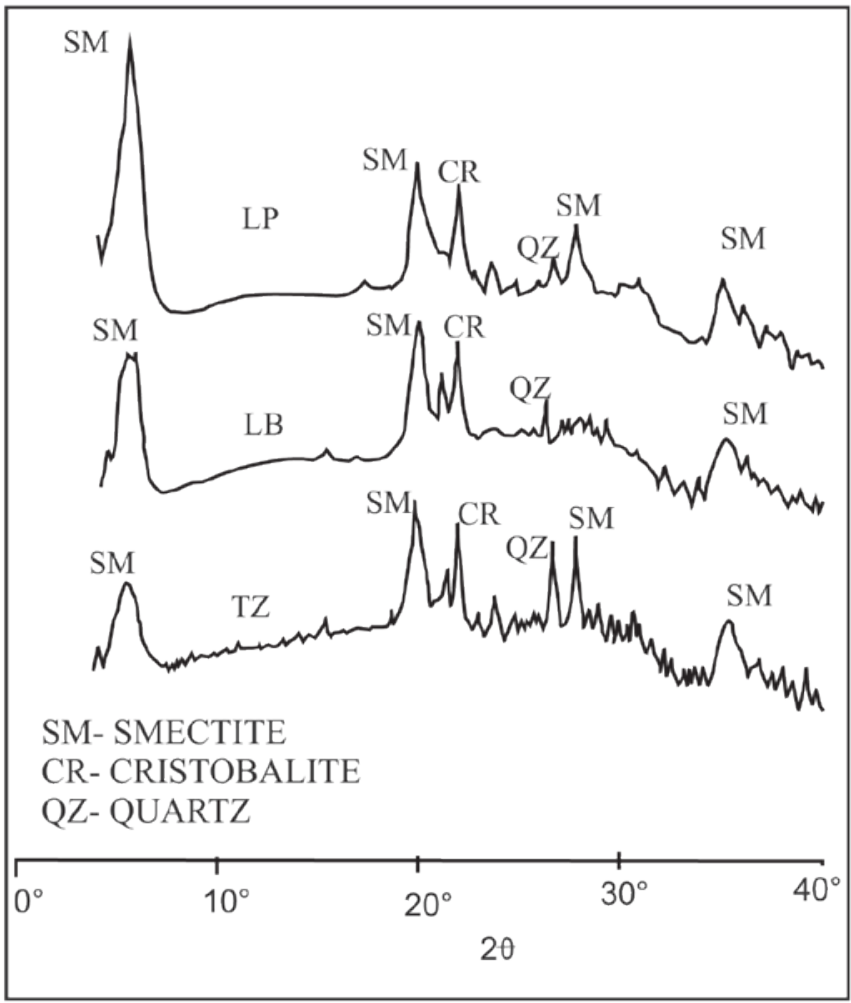

b)

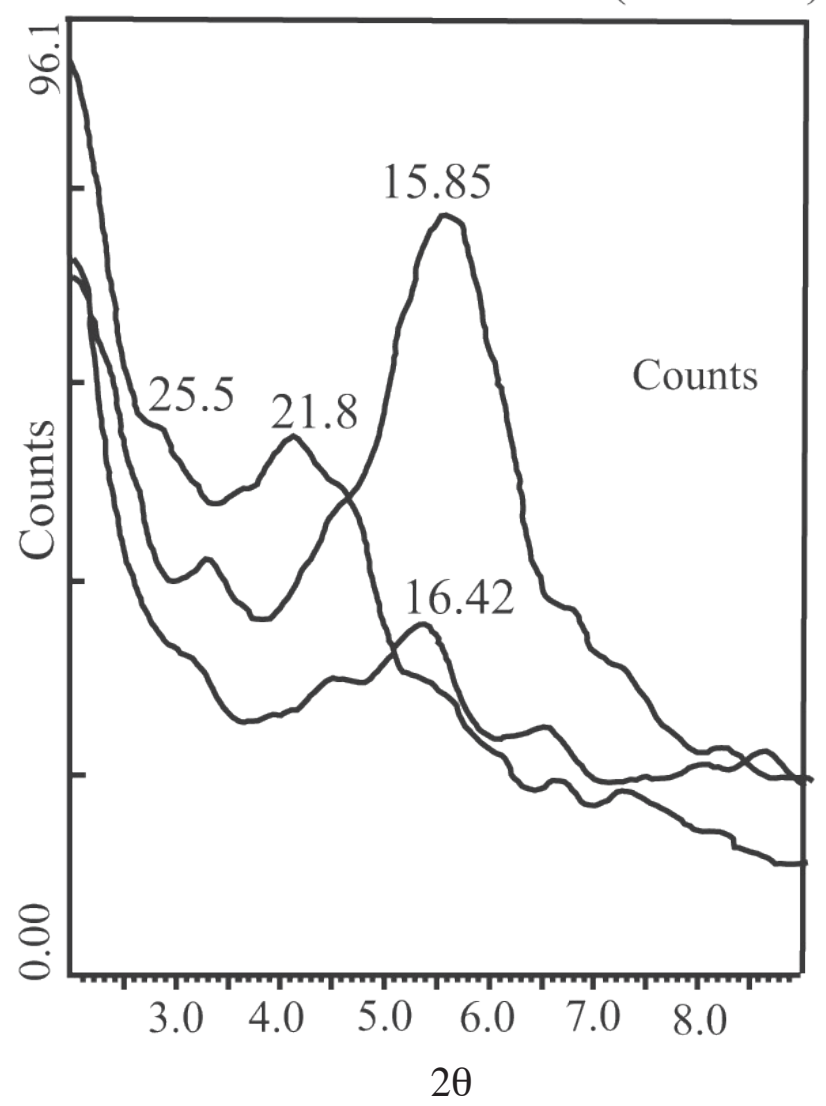

c)

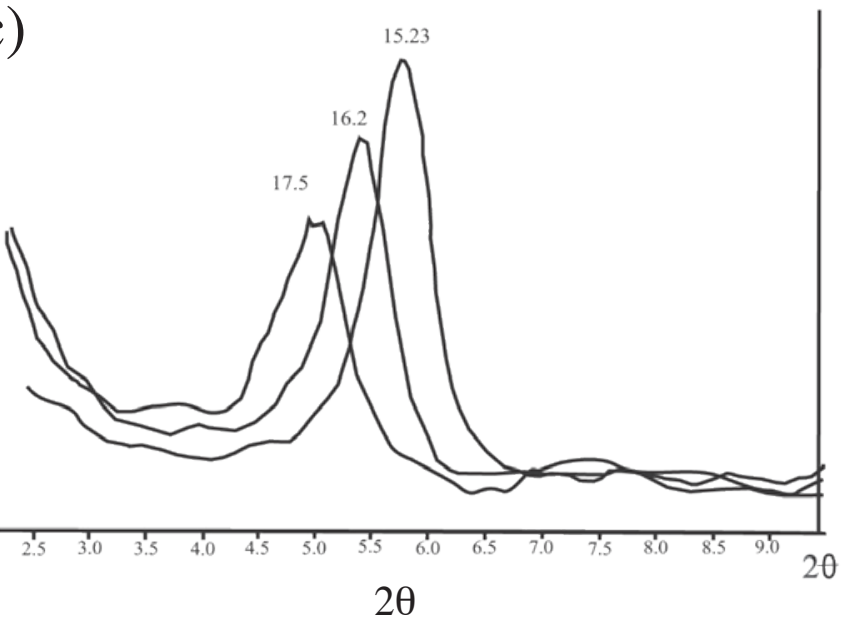

Figure 4. a) Diffraction patterns of clayey samples from Las Pulgas (LP), Lomas Blancas (LB) and Tzitzimeo (TZ) sites showing, b) X-Ray diffratograms of the natural Charo clays $(\mathrm{d}=15.85 \AA)$ after humidification $(\mathrm{d}=21.08 \AA)$ and glycolation $(\mathrm{d}=16.42 \AA)$, c) X ray diffractograms of hydrated and glycolated Na-Montmorillonite clay indicating a regular d-shift.

\subsection{Diatoms as indicators}

The main features of the considered assemblages and their paleoenvironmental significance are described in Figure 7. Only diatoms with an abundance of $>5 \%$ are shown in the diagrams. Reference to species as subdominant or dominant follows the terminology of Gasse et al. (1986), where dominant species vary from $33 \%$ and subdominant species from 5 $<33 \%$ of the count. In the Charo paleolake sector the interlaid diatomite and ash levels are common over the clayey strata, indicating an initial lake with intermittent volcanic activity in the zone. Observations of sampled diatoms in the central sector shows that, at Las Pulgas (LP), the association of Mastogloia elliptica var dansei (Twaites), Cleve Muller, Rophalodia gibba (Ehrenberg), Cymbella cymbiformis (Agard), Epithemia sorex (Kutzing) and Punctastriata pinnata (Ehrenberg) (Figure 7), all of which are tolerant to high alkalinity (Gasse, 1986) and characteristic of low lacustrine levels.

At the Lomas Blancas (LB) site, clays are about $0.80 \mathrm{~m}$ thick and are composed of very compact black clay, which has a conchoidal type fracture in contact with a fine $(0.5 \mathrm{~cm})$, oxidized yellow level. This zone is the most visible of all the sections and is characterized by an important exposure of whitish sediments; the colour is due to the diatomite deposits and its base correlates well with the LP section. The LB site shows a homogeneous community of diatoms that inhabit planktonic environments with high silica levels, Thalassiossira cuitzeonensis (Serieyssol et al., 1998) and Aulacoseira praegranulata (Jousé) being characteristic. Also, a conglomerate occurs at the top level of this section that covers the topographic surface. This horizon can be followed laterally, where it shows heterotopias with some sandy layers containing small volcanic rock clasts.

At Tzitzimeo (TZ) zone (Figure 2c), only an isolated outcrop is exposed, which probably belongs to the middle mem- 


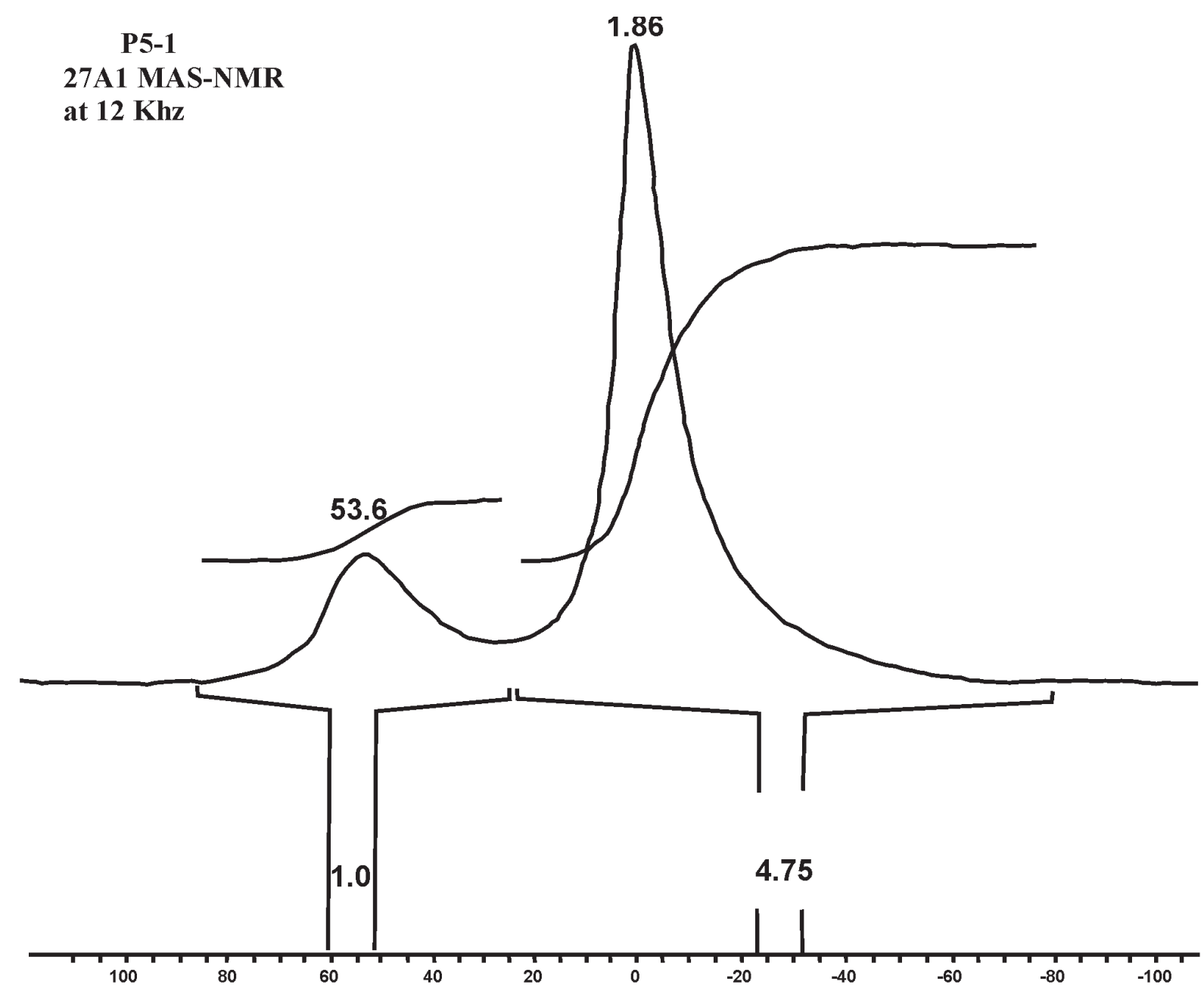

Figure 5. $27 \mathrm{Al}-\mathrm{NMR}$ spectrum of a Charo selected clay, with $\mathrm{Al}(\mathrm{IV})$ and $\mathrm{Al}(\mathrm{VI})$ peak areas indicated, i.e. $\mathrm{Al}(\mathrm{IV}) / \mathrm{Al}(\mathrm{VI})=4.75$.

ber of the Charo Formation. Diatoms are not well preserved, although they are characteristic of low lacustrine levels. Geochemically, the absence of sodium ions in the sediments indicates that evaporation processes were not important at all, but it could be possible that higher lacustrine levels occurred.

Regionally, the diatom-bearing strata are covered by conglomerates that evidence the effect of fluvial erosion at the top of the sequence. Capping the sequence there is a $1 \mathrm{~m}$ thick outcrop of pyroclastic fall-deposits, which is composed of reworked pumice.

\section{Conclusions}

Tectonics has induced changes in the Neogene Cuitzeo graben with water level modifications and filling by silted and epiclastic facies associated to diatomaceous and clayey horizons. The finest minerals of these zones were identified as beidellitenontronite smectites. The basal members of LP 5, LB 1 and TZ levels have similar mineralogical characteristics, such as fine strata of 3 to $5 \mathrm{~cm}$ in thickness, uniform clay grain size $(<2 \mu)$, doughy texture, dark brown to black colour; and other physical properties like lustre appearance and a conchoidal type fracture.

The characterization of the clays by Mössbauer spectroscopy and ${ }^{27} \mathrm{Al}-\mathrm{NMR}$-solid state analysis indicated that the basal LP 5 clays consisted of beidellite-nontronite series, which are similar to beidellite, i. e. about one out of four aluminium atoms are in a tetrahedral symmetry $\left(\mathrm{Al}^{\mathrm{IV}}\right)$. According with Mössbauer spectroscopy data, most of the LB, LP, and TZ clays are composed by a mixture of beidellite-nontronite member. These clays are not very common and only few ore deposits have been reported so far (Brindley and Brown, 1984; Coban and Ece, 1997).

On the basis of the geological and chemical evidences, it is very possible that $L P, L B$ and TZ deposits were a portion of the same lacustrine basin at Miocene-Pliocene times. The parent rocks were mainly andesitic, but other felsic rocks (dacites, ignimbrites) surrounded the palaeolake. Also, the formation of smectites with special physical and chemical properties was favoured by the prevailing reducing conditions and by the infiltration of leached ions from upper strata.

The EDS individual and XRF analyses in clays near the LP site, indicate poor $\mathrm{Na}+$ concentration, i.e., of about $0.14 \%$ wt, 

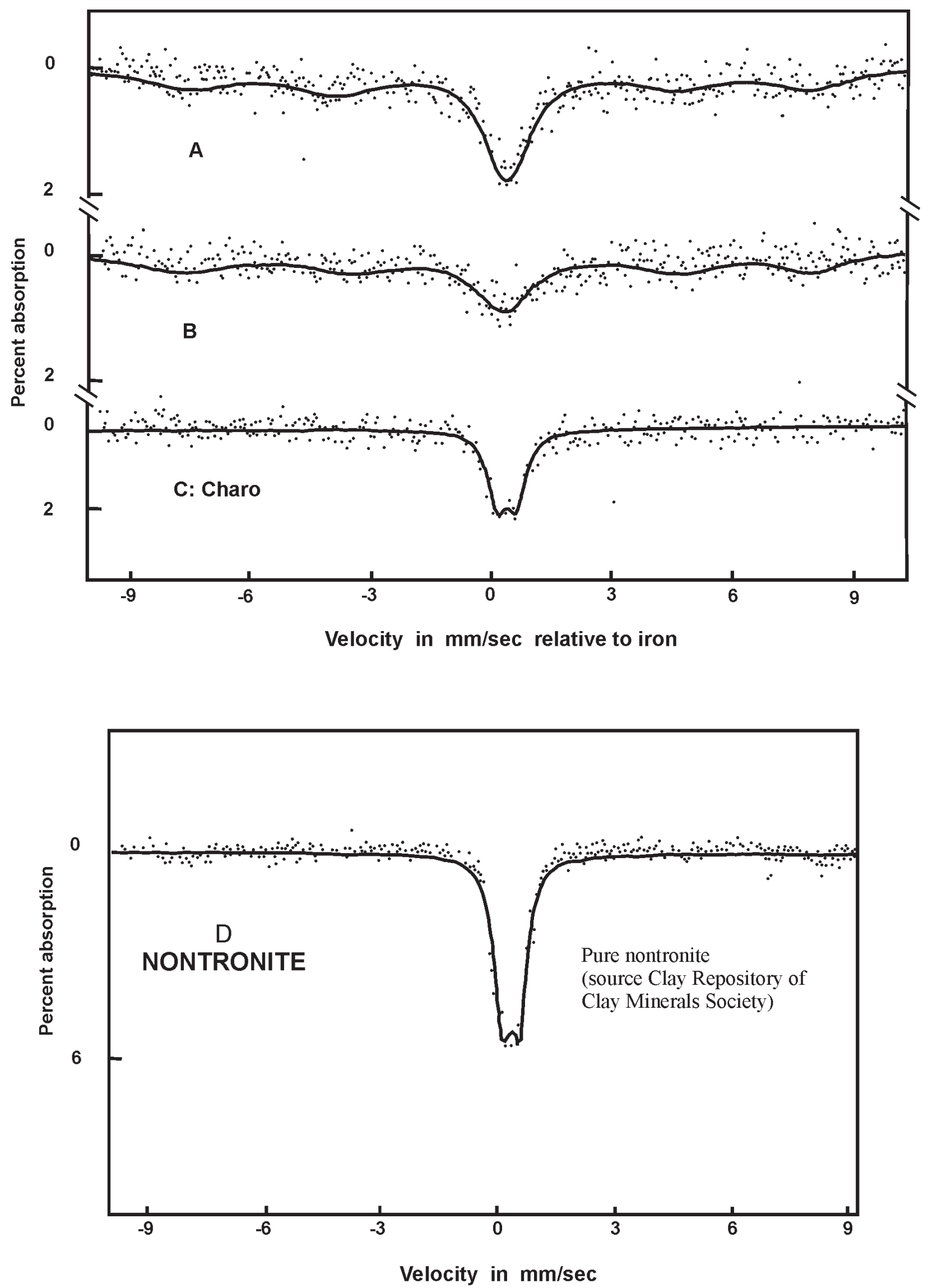

Figure 6. Mössbauer spectra of typical Montmorillonite (A,B), Charo clays (C) and Nontronite (D). 

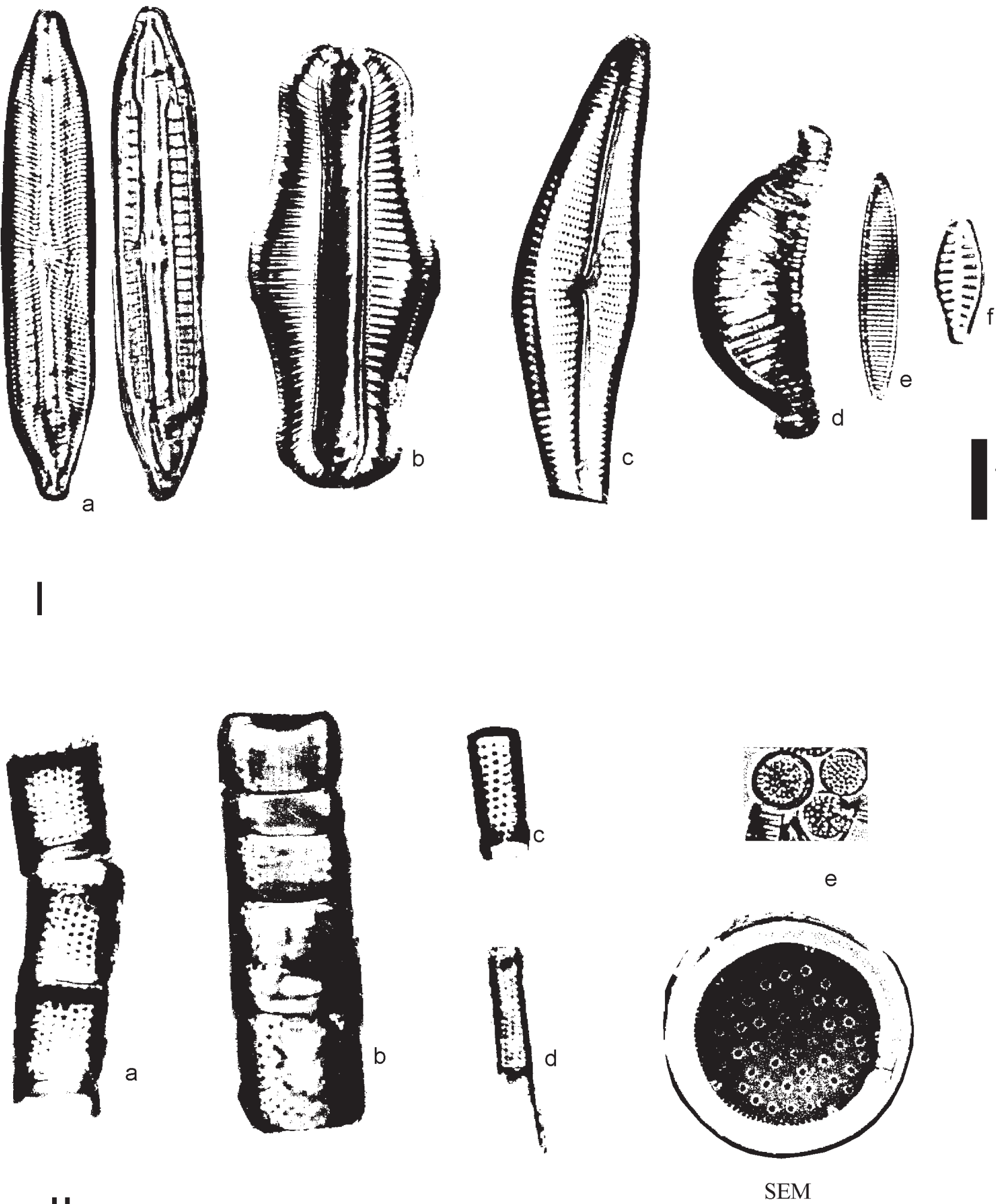

II

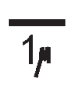

Figure 7. Characteristic diatoms from Cuitzeo paleolake and paleoecological preferences. 
which is related to higher lacustrine levels. The same characteristics are supported by the presence of diatom taxa indicative of planktonic habitats.

From the paleoenvironmental point of view, it may be concluded that: a) the presence of fine-textured, massive clays on the basal and middle members of lacustrine beds indicate that the lacustrine basin contained a very stable body of water without strong streams nor big arrivals of coarser materials at the beginning of this succession; as is shown by the fine granulometry of sediments and the absence of evidence of synsedimentary structures; b) at the LP site, the initial lake was part of a small depression in which the diatom association evidences a swampy environment. In a consecutive and more humid period, the lake extended over the whole area; that is why, at the LB site, the overlaying diatom deposits indicates a turbid and deep water level, which is evidenced by the presence of Aulacoseira praegranulata (Gasse, 1986), while in the margins of the basin the diatom associations indicate swampy environment, with a lower water level, in agreement with the presence of littoral (Cymbella sp. and Fragilaria sp.) and/or planktonic facultative forms; c) the absence of $\mathrm{Na}+$ in the sediments suggest a poor evaporation processes in the evolution of this basin.

\section{Acknowledgements}

The present work was possible thanks to financial support from Conacyt, SIMORELOS 1998 306010. The authors thank Dr. Miguel García Silva for corrections to the text and the kind observations of Dr. James Bischoff from the USGS, Menlo Park Ca.

\section{References}

Anda, L., 1956, Vulcanología del Cenozoico. XX: Congreso Internacional de Geología, U.N.A.M., México.

Brindley, G. W., Brown, G., 1984, Crystal structures of clay minerals and their X-ray identification: Mineralogy Society, Monography, 5, U. K.

Carbajal de la Torre, G., Israde-Alcántara, I., Serrato Rodriguez, J., Reyes Gasga, J., 1998, Electron microscopy and X-Ray Analysis of Lacustrine clays from the Charo canyon State of Michoacan, Mexico: Clays and Clay Minerals, 46 (3), 330-339.

Carranza-Castañeda, O., 1976, Rhyncotherium falconeri del rancho La Goleta, Michoacán, Mexico: Congreso Latinoamericano de Geología, Instituto de Geología U.N.A.M., 3, Memoria 3, 28.

Coban, F., Ece, O. I., 1997, Origin and ocurrences of nontronites in Ayvacik bentonite deposit, Biga Peninsula, NW Turkey (abstract), in The 11th International Clay Conference, June 15-21, Carleton University Ottawa, Ontario, Canada, A17.

Comisión Federal de Electricidad (CFE), 1986, Muestra CU-8. Dataciones radiométricas en rocas del NW de Michoacán: Oficina de Geología. Reporte GG 10/86 inédito, 14 p.

Demant, A., Mauvois, R. Silva-Mora, L., 1975, Estudio geológico de las hojas Morelia-Maravatío (escala 1:100000), Estado de Michoacán: Instituto de Geología, U.N.A.M., Informe a la CFE inédito, 30 p.

De Pablo-Galán, L., 1976, Attapulgita sedimentaria marina de Yucatán, México: Instituto de Geologia U.N.A.M., Boletín 96, 3-30.

De Pablo-Galán, L.,1990, Diagenesis of Oligocene-Miocene vitric tuffs to montmorillonite and K-feldspar deposits, Durango, México: Clays and Clay Minerals, 38, 426-436.

Garduño, V. H., 1988, La Caldera de Los Azufres y sus relaciones con el sistema regional E-O: Geotermia, Revista Mexicana de Geoenergía, 4, 49-61.

Garduño-Monroy, V. H., Spinnler, J., Ceragioli, E., 1993. Geological and structural study of the Chapala rift, State of Jalisco, Mexico: Geofísica Internacional, 32(3), 487-499.

Gasse, F., 1986, East African Diatoms, Taxonomy, Ecologycal Distribution. Biblioteca diatomologica: Berlin Stuckard. 203 p.

Heller-Kalai, L. Wones, D. R., 1981. The use of Mössbauer spectroscopy of iron in clay mineralogy: Physical Chemical Minerals, 7, 223-238.

Irvine, T. N., Baragar, W. R. A., 1971, A guide to the chemical classification of the common volcanic rocks: Canadian Journal of Earth Sciences, 8, 523-548.

Israde-Alcántara, I., 1995, Bacini Lacustri dal Settore Centrale dall'arco vulcanico messicano. Stratigrafia ed evoluzione vulcanotettonica basata sulle diatomme: Unpublished $\mathrm{PhD}$ dissertetion. Università degli Studi di Milano, 254 p.

Israde-Alcántara, I., 1997, Neogene Diatoms of the central sector of the Mexican Volcanic belt (Cuitzeo lake) and its relationship with the volcanotectonic evolution: Special publication. Quaternary International, 43/44: 137-143.

Israde-Alcántara, I., Garduño-Monroy, V. H., 1999, Lacustrine record in a volcanic intra-arc setting: The evolution of the Late Neogene Cuitzeo Basin System (Central Western Mexico): Ancient and Recent lacustrine systems in convergent margins (Special Issue). Cabrera, L., Saez, A. (eds). Paleogeography, Palaeoclimatology, Palaeoecology. 151, (1-3). 209-227.

López-Ramos, E., 1974, Geología General y Geología de México, U.N.A.M., $509 \mathrm{p}$.

Nolet, D. A., Burns, R. G., 1979. A study of temperature dependent electron delocalization by the Mössbauer effect: Physical Chemical Minerals, 4, 221-234.

Ortega-Gutiérrez, F., Mitre-Salazar, L. M., Roldan-Quintana, J., Aranda-Gomez, J. J., Morán Zenteno, D., Alaníz-Alvarez, S. A. Nieto-Samaniego, A. F., 1992, Carta Geológica de la República Mexicana. Escala 1- 2 000,000. Instituto de Geología U.N.A.M. y Consejo de Recursos Minerales, 74 p.

Quintana-Puchol, R., Bribiesca Hernández S., Garduño Monroy, V. H., 1999, Caracterización mineralógica de los caolines del yacimiento Los Azufres del estado de Michoacán, México: Revista Mineralogía y Geología, 16 (1), 32-42.

Rosas-Elguera, J., Ferrari L., López Martínez M., Urrutia-Fucugauchi, J., 1997, Stratigraphy and Tectonics of the Guadalajara Region and Triple-Junction area, Western Mexico: International Geology Review, 39, 125-140.

Rodríguez-Pascua, M. A, Garduño-Monroy, V. H., Israde-Alcántara, I., 2004, Terremotos pleistocenicos en la cuenca lacustre de Acambay (México). VI Congreso Geológico de España. Geotemas. 6 (3), 183-186.

Serieyssol, K. K, Israde, G. I., Gasse, F., 1998. Thalassiosira dispar comb. nov. and T. Cuitzeucensis spec. nov. Bacillariophiceae found in Miocene sediments from France and Mexico: Nova Edwigia, Stuttgart, 66, 177-186.

Suter, M., Quintero, O., Johnson, C. A., 1992, Active faults and state of stress in the central part of Trans-Mexican Volcanic Belt, Mexico, The Venta del Bravo Fault: Journal Geophysical Research, 97, 11983-11994.

Suter, M., López-Martínez, M., Quintero-Legorreta, O., Carrillo-Martínez, M. 2001, Quaternary intra-arc extension in the central Trans-Mexican volcanic belt: Geological Society of America Bulletin, 113 (6), 693-703.

Vargas-Rodriguez, Y. M., Gomez-Vidales, V., Vazquez-Labastida, E., GarcíaBorquez, A., Aguilar Sahún, G., Murrieta-Sanchez, H., Salmón, M., 2008, Caracterización espectroscópica, química y morfológica y propiedades superficiales de una montmorillonita mexicana: Revista Mexicana de Ciencias Geológicas, 25 (1), 135-144.

Von Erffa, A., Hilger, W., Knoblich, R., Weyl, R., 1976. Geología de la Cuenca Alta de Puebla Tlaxcala y sus contornos: Comunicaciones. Proyecto Puebla-Tlaxcala, México, 13, 99-106

Manuscript received: June 27, 2008

Corrected manuscript received: July 7, 2008

Manuscript accepted: August 4, 2008 